\title{
Holocene and Late Glacial sedimentation near steep slopes in southern Lake Baikal
}

\author{
Michael STURM, ${ }^{1 *}$ Elena G. VOLOGINA, ${ }^{2}$ Svetlana S. VOROB'EVA ${ }^{3}$
}

${ }^{1}$ EAWAG-ETH, 8600 Dübendorf-Zürich, Switzerland; ${ }^{2}$ Institute of the Earth's Crust, SB RAS, 664033 Irkutsk, Russia; ${ }^{3}$ Limnological Institute, SB RAS, 664033 Irkutsk, Russia

*Corresponding author: michael.sturm@emeriti.eawag.ch

\begin{abstract}
We here present new data on sedimentation at and near the steep north-slopes of southern Lake Baikal. Short sediment cores were taken at $550 \mathrm{~m}$ and at $1366 \mathrm{~m}$ water depth, within $3600 \mathrm{~m}$ offshore Cape Ivanovskii at the station of the Baikal Deep Underwater NEUTRINO Telescope. The sediments within $3600 \mathrm{~m}$ off the northern coast of Southern Lake Baikal are dominated by pelagic deposition. Our data reveal surprisingly little influence from terrigenous material from adjacent coastal areas, tributaries and their catchment. At the shallow-water site (at $550 \mathrm{~m}$ water depth, $700 \mathrm{~m}$ off shore) just $27 \mathrm{~cm}$ thick homogenous sediments have accumulated during the Holocene on top of Pleistocene deposits resulting in Holocene sedimentation rates of $0.003 \mathrm{~cm} \mathrm{a}^{-1}$. The very low rates are caused by long-term persistent winnowing of fine particles caused by week contour currents along the slope. The uppermost sediments are oxidized down to $22 \mathrm{~cm}$. Very low concentrations of $C_{\text {org }}, \mathrm{Si}_{\text {bio }}$ and $\mathrm{N}_{\text {tot }}$ in Pleistocene sediments increase dramatically within the Holocene. The heavy mineral fraction of the shallow-water sediments contains up to $33.6 \%$ olivine and up to $2.4 \%$ spinel. These rare minerals originate from white marbles of the nearby coastal outcrop Belaya Vyemka of the Early Precambrian Sharyzalgaiskaya Series. At the deep-water site (at $1366 \mathrm{~m}$ water depth, $3600 \mathrm{~m}$ off shore) Holocene sedimentation rates are 10-times higher $\left(0.036 \mathrm{~cm}^{-1}\right)$. Sediment oxidation occurs just within the uppermost $2 \mathrm{~cm}$. Of the two rare type minerals of the Sharyzalgaiskaya Series spinel does not occur at all and olivine is represented by very diminished concentrations. This indicates insignificant influx of terrestrial material from the nearby shore to the deep-water site. Distal turbidites of far-off sources are intercalated to pelagic sediments at the deep-water site. Breakdown events of deltas at the $S E$ - and $S$-coast of the basin are suggested to be responsible for the formation of the turbidites. They contain terrestrial (deltaic) material, low amounts of biological material (diatoms, spiculae, chrysophyte cysts), low concentrations of $S i_{\text {bio }}$, $C_{\text {org }}$ and $N_{\text {tot }}$ and occur at approximate recurrence rates of 300 years.
\end{abstract}

Key words: Lake Baikal; near-shore sedimentation; winnowing; sedimentation rates; turbidites, diatom stratigraphy; spinel; olivine.

Received: March 2015. Accepted: June 2015.

\section{INTRODUCTION}

Lake Baikal is the world's oldest lake and has accumulated up to $8 \mathrm{~km}$ of sedimentary deposits. It is also the world's deepest lake, holding $20 \%$ of the world's surface freshwater reserves and the world largest amount of endemic species. In order to extensively assess environmental impacts on Lake Baikal, their recent and their longer-term history, and their potential influence into the future, it is important to have comprehensive knowledge on the forcing mechanisms and processes, which are responsible for these changes. Research papers of different scientific disciplines have contributed background knowledge on the formation of Lake Baikal and the dynamics of its vast water mass (Goldyrev, 1982; Bezrukova et al., 1991; Shimaraev et al., 1993; Khozhova and Izmest'eva, 1998). It has been shown that biological, physical and geochemical processes all influence biological and geochemical variability in the lake (Mackay et al., 1998; Flower, 1998; Müller et al., 2005; Granina and Callender, 2007; Schmid et al., 2008). Detailed studies of the lake bottom morphology and of composition and age of sediments in the different basins have been used, to further our understanding of processes of sed- iment formation and accumulation in Lake Baikal (Potrik'eva, 1959; Karabanov et al., 1984; Appleby et al., 1998; De Batist et al., 2002; Colman et al., 2003; Vologina and Sturm, 2009) and to studying past environmental and climate changes (Kuzmin et al., 2000; Bangs et al., 2000; Grachev et al., 2002; Fietz et al., 2005; Mackay, 2007). Formation and deposition of turbidities within the deep basins of Lake Baikal have been investigated and described within the conceptual principles of turbidity current formation in freshwater basins (Sturm and Matter, 1978). Within Lake Baikal they are triggered by earthquakes, catastrophic floods in the catchment and by methane gas eruptions (Lees et al., 1998; Nelson et al., 1999; Back et al., 1999; De Batist et al., 2002; Vologina et al., 2003; Vologina et al., 2012).

In this paper we present new data, which demonstrate the marginal influence of terrigenous coastal material on near-shore sites at steep slopes of Lake Baikal, which as yet has been poorly studied. The data have been gathered during several expeditions (between 2000 to 2010) to the station of the NEUTRINO NT200 Telescope (Belolaptikov et al., 1998) near Cape Ivanovskii at the northshore of the South Basin. Our paper explores the source 
of coastal/terrestrial material, its limited near-shore deposition and its little influence on deep-water sedimentation within regions less than $3600 \mathrm{~m}$ off a steep coastal slope of a lake.

\section{Geological characteristics}

Early Precambrian rocks of the Sharyzalgaiskaya Series form most of the N-coast of the south basin of Lake Baikal (Fig. 1). They consist of biotite, biotite-garnet, hyperstene, granitic gneisses, crystalline slates, pyroxene-magnetite quartzites, amphibolite spinel-forsterite marbles and calciphyres (Khrenov, 1983; Salnikova et al., 2007; Melnikov, 2011). A prominent $1.5 \mathrm{~km}$ long outcrop, Belaya Vyemka, of the Sharyzalgaiskaya Series is exposed to the east of the NEUTRINO Telescope Station (Fig. 2); it is characterized by white marbles and calciphyres (Melnikov, 2011) and contain the very rare type-minerals olivine $\left.(\mathrm{MgFe})_{2} \mathrm{SiO}_{4}\right)$ and spinel $\left(\mathrm{MgAl}_{2} \mathrm{O}_{4}\right)$. The outcrop was generated during the construction of the Trans-Siberian Railway tracks along the shores of Lake Baikal (Krugobaikalskaya) at the beginning of the $20^{\text {th }}$ century (Marks, 1991).

The lake morphology near this site comprises a very steep, cliff-like slope, which descends down to the $>1300$ $\mathrm{m}$ deep, flat basin plain within less than $2 \mathrm{~km}$ from the shore. This abrupt morphology is caused by the main, WE striking Cenozoic Obruchevskii fault (Khrenov, 1983). The drainage area along the $\mathrm{N}$-coast is very small with only small stream-like tributaries, transporting minor amounts of runoff particles into the lake.

\section{METHODS}

A total of four sediment cores were collected during winter months in 2000, 2008 and 2010 from the ice-covered lake at two sites offshore of the NEUTRINO telescope station (Tab. 1). Two cores were taken $700 \mathrm{~m}$ offshore at $550 \mathrm{~m}$ water depth (shallow-water site), situated on a small morphological platform at the steep slope. This platform was discovered in 1986, during a detailed bathymetric survey for the NEUTRINO Telescope Station by V.A. Fialkov and E.B. Karabanov, Limnological Institute, Irkutsk. Two cores were taken $3600 \mathrm{~m}$ offshore on the flat basin plain at $1366 \mathrm{~m}$ water depth (deep-water site) (Fig. 1). All coring stations were exactly relocated using GPS from the ice. Water depths were measured by counting meters of wire released by motorised winches.

Two types of gravity corer were used to collect short cores (UWITEC-63 and EAWAG-63/S), and transparent PVC-tubes of $63 \mathrm{~mm} \varnothing$ were used with both corers to ensure complete, undisturbed core recovery (including the delicate water/sediment interface). After recovery the cores were cut longitudinally, photographed and analysed for detailed lithology, using smear slides under a light microscope SK14 with a magnification of 100x. Addition- ally, sediments of five streams near Cape Ivanovskii were sampled for the characterization of tributary material: i) Polovinnaya; ii) Bolshaya Ponomaryvka; iii) Ivanovka; iv) Stream; and v) Shumiha (Fig. 1). All stream samples were analysed for grain size and mineral composition, as described below.

The lithological description of the cores included the characterization of biogenic material and the assessment of grain sizes and terrigenous particles. One half of each core was sampled continuously in intervals of $0.5 \mathrm{~cm}$ from $0-10 \mathrm{~cm}$, and in intervals of $1 \mathrm{~cm}$ for the rest of core for detailed analyses of $\mathrm{C}_{\text {tot }}, \mathrm{N}_{\text {tot }}, \mathrm{Si}_{\text {bio }}$, grain size and diatom determination. $\mathrm{C}_{\text {tot }}$ and $\mathrm{N}_{\text {tot }}$ were determined by a gas chromatograph (HEKATECH Euro $\mathrm{AE}^{\circledR}$ Elemental Analyser). $\mathrm{C}_{\text {org }}$ was calculated by subtraction of $\mathrm{C}_{\text {inorg }}$ (determined by a $\mathrm{CO}_{2}$-COULOMETER) from $\mathrm{C}_{\text {tot }}$. The analysis of $\mathrm{Si}_{\text {bio }}$ followed the method of Ohlendorf and Sturm (2008). Non-pretreated, freeze-dried samples were leached by $1 \mathrm{M} \mathrm{NaOH}$ under ultrasonic treatment in Teflon ${ }^{\circledR}$ autoclaves at $100^{\circ} \mathrm{C}$ without stirring. Complete leaching was checked by SEM examination for the absence of scales of diatoms, chrysophytes, spicules, etc. Concentrations of $\mathrm{Si}, \mathrm{Al}$ and $\mathrm{Na}$ were determined by ICPOES. Al and $\mathrm{Na}$ were used to correct for the amount of potentially leached minerals. Diatom analyses of cores BAIK08-2 (42 samples) and BAIK10-4 (82 samples) with sampling intervals of $1 \mathrm{~cm}$ were performed according to Grachev et al., 1997. A MALVERN-MASTERSIZER ${ }^{\circledR}$ Hydro 2000S was used to measure grain-sizes of core BAIK00-1. To reduce the effect of diatoms, chrysophyte cysts and spiculae of sponges on the interpretation of grain size distributions, grain size analyses were performed on both, bulk samples and samples without $\mathrm{Si}_{\text {bio }}$. Light and heavy minerals of cores BAIK08-1 and BAIK08-2 were separated by bromoform $\left(2.7 \mathrm{~g} \mathrm{~cm}^{-3}\right)$ and determined under oil immersion with a MIN-8 microscope using the fraction $50-250 \mu \mathrm{m}$. The amounts of sand $(>50 \mu \mathrm{m})$ and silt $(5-50 \mu \mathrm{m})$ fractions were determined by sieving. The clay fraction $(<5 \mu \mathrm{m})$ was separated by elutriation (grain size classification by Rukhin 1969).

The chronology of recent sediments was determined by radiometric dating, using measurements of ${ }^{210} \mathrm{~Pb}$ (half-life: 23.3 years) and ${ }^{32} \mathrm{Si}$ (half-life: 144 years). ${ }^{210} \mathrm{~Pb}$ activities were measured by $\gamma$-counting of freeze-dried sediment samples (at intervals of $0.5 \mathrm{~cm}$ ) for $24 \mathrm{~h}$ in a calibrated CANBERRA $\mathrm{Ge}(\mathrm{Li})$ borehole detector. Sedimentation rates were calculated using the CRS (Constant Rate of Supply) model. Ages of the uppermost turbidites of core BAIK00-1 were taken from Morgenstern et al., 2013, who used radioactive ${ }^{32} \mathrm{Si}$ (half-life: 144 years) to determine the sedimentation rates of deep-water sediments during the last millennium. AMS $-{ }^{14} \mathrm{C}$ was not used in our study to date older sediments, because of ambiguous results reported for Lake Baikal sediments by Watanabe et al., 2009. 


\section{RESULTS}

\section{Lithology of sediments}

The uppermost sediments of the shallow-water cores BAIK08-1 and BAIK10-4 (Fig. 1, Tab. 1) consist of dark greenish-grey, homogenous silty clay with admixtures of sand. Smear-slide analyses show abundant pelagic diatoms and spiculae of sponges. The uppermost part of the sediments is oxidized, represented by a zone of dark to light brown, yellowish colours, which is underlain by lay-
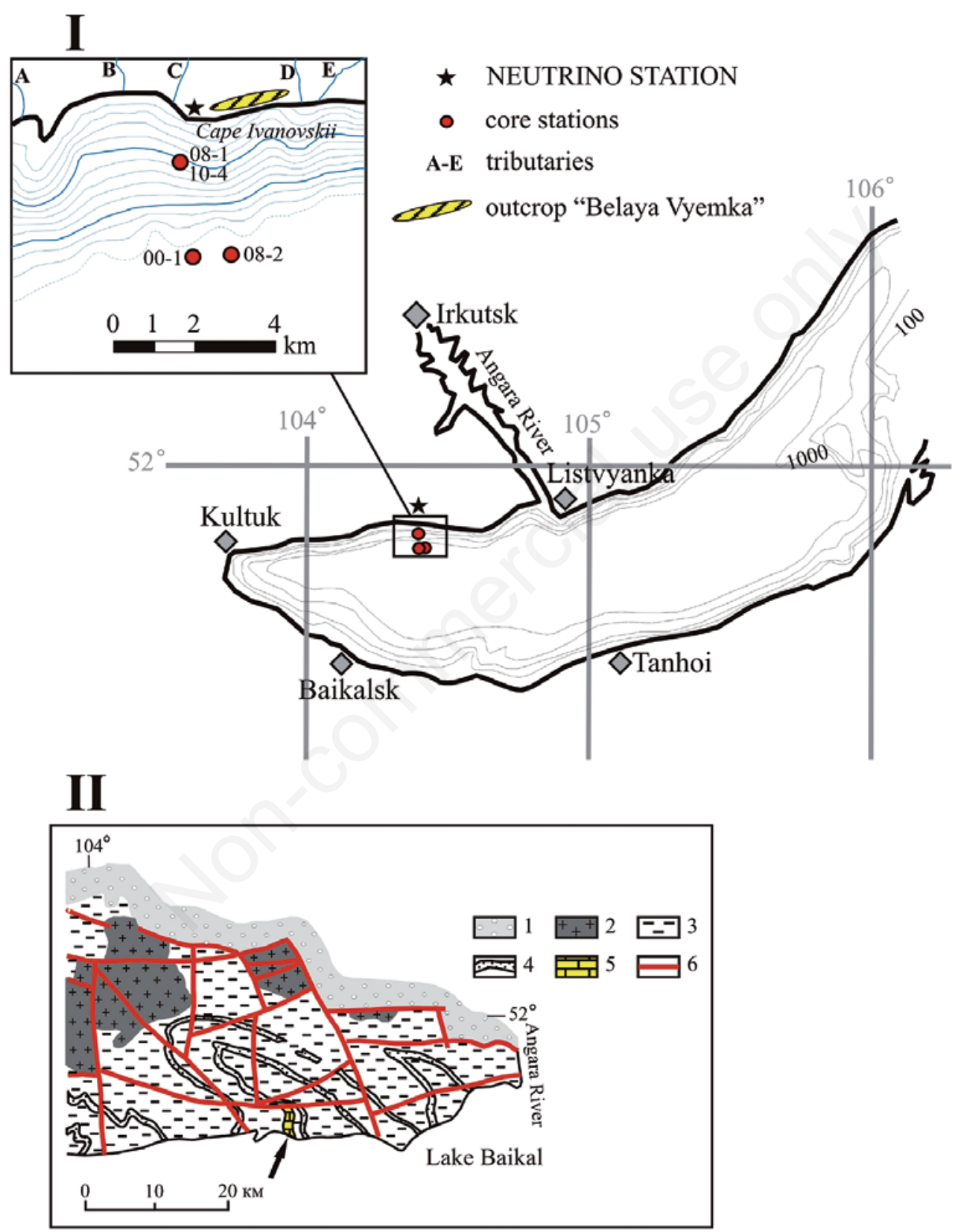

Fig. 1. Bathymetry of southern Lake Baikal. I) Core locations at shallow-water (BAIK08-1, BAIK10-4) and at deep-water (BAIK001, BAIK08-2); also shown are the outcrop Belaya Vyemka and the position of five tributaries, sampled near the NEUTRINO-telescope station at Cape Ivanovskii; A, Polovinnaya; B, Bolshaya Ponomaryvka; C, Ivanovka; D, Stream; E Shumiha. II) Geological sketch map of the area (after Melnikov, 2011), depicting rocks of the Sharyzalgaiskaya Series and the outcrop Belaya Vyemka (black arrow); Legend of geological map: 1, Neoproterozoic-Early Paleozoic cover of the Sibirian Craton; 2, Paleoproterozoic granites of the Sayanskyi Complex; 3, Archean granitic gneisses; 4, Archean biotite-garnet gneisses, 5, Archean forsterite marbles and calciphyres of Belaya Vyemka, containing the rare minerals olivine and spinel; 6 , fault lines. 
ers of dark brown to black Fe/Mn-crusts. The total thickness of the oxidized zone is $20.0 \mathrm{~cm}$ in core BAIK08-1 and $21.5 \mathrm{~cm}$ in core BAIK10-4. The lower parts of the cores are formed of lighter grey, homogenous clayey silt with abundant admixtures of terrigenous particles. Turbidites (graded beds) and sand layers do not occur in the shallow-water cores. Sediments of deep-water cores BAIK00-1 and BAIK08-2 (Fig. 1, Tab. 1) consist also of dark, greenish-grey, homogenous, silty-clayey sediments but with smaller amounts of sand. Planktonic diatoms, chrysophyte cysts and spiculae of sponges form up to $40 \%$, organic material up to $10 \%$ and fine terrigenous particles $<30 \%$ of these deposits (Ohlendorf and Sturm, 2008). Just the uppermost $2 \mathrm{~cm}$ (BAIK00-1) and $2.8 \mathrm{~cm}$ (BAIK08-2) are oxidized, showing a zone of light to dark brown colours. Older, olive-brown to dark brown oxidized layers appear at $6.0 \mathrm{~cm}$ (BAIK00-1) and $8.0 \mathrm{~cm}$ of BAIK00-1 and at $7 \mathrm{~cm}$ to $7.5 \mathrm{~cm}$ of BAIK08-2.

The pelagic deep-water sediments are intercalated occasionally by turbidites (graded beds), which are clearly distinguishable by their darker colour, by upward grading from sand to silt and clay and by the higher amount of ter- restrial plant remains. In core BAIK00-1 four turbidites could be observed with a thickness between $3 \mathrm{~cm}$ and 29.5 $\mathrm{cm}$ (14.5-19.0 cm, 32.5-35.5 cm, 48.8-57.5 cm, 79.0$108.5 \mathrm{~cm})$. The two uppermost turbidites $(14.5-19.0 \mathrm{~cm}$ and $32.5-35.5 \mathrm{~cm}$ ) could be correlated to turbidites of the shorter parallel core BAIK08-2 at 15-18 cm and 27.9-31.6 cm (Figs. 3 and 4).

\section{Results of diatom analysis}

In shallow-water sediments (BAIK10-4) numbers of diatoms, vary widely and are dominated by planktonic diatoms (Fig. 2). Within 0-27 cm they show a first maximum of 1.2-104× $10^{6}$ valves $\mathrm{g}^{-1}$ (benthic diatoms: $0.05-1.19 \times 10^{6}$ valves $\mathrm{g}^{-1}$, chrysophyte cysts: $0.26-23.4 \times 10^{6}$ specimens $\mathrm{g}$ ${ }^{1}$, spiculae: $10-110 \times 10^{3}$ specimens $\left.\mathrm{g}^{-1}\right)$. The most common diatom species are Cyclotella minuta (Skvortzow) Antipova (6.7-96.3\%), Aulacoseira baicalensis (K. Meyer) Simonsen (0.6-62.1\%), Aulacoseira skvortzowii Edlund, Stoermer et Taylor + spores (0.2-57.2\%), Cyclotella baicalensis Skvortzow (0.6-6\%), Cyclostephanos dubius (Früke) Round (0.01-5.3\%), Synedra acus Kützing (0.01-

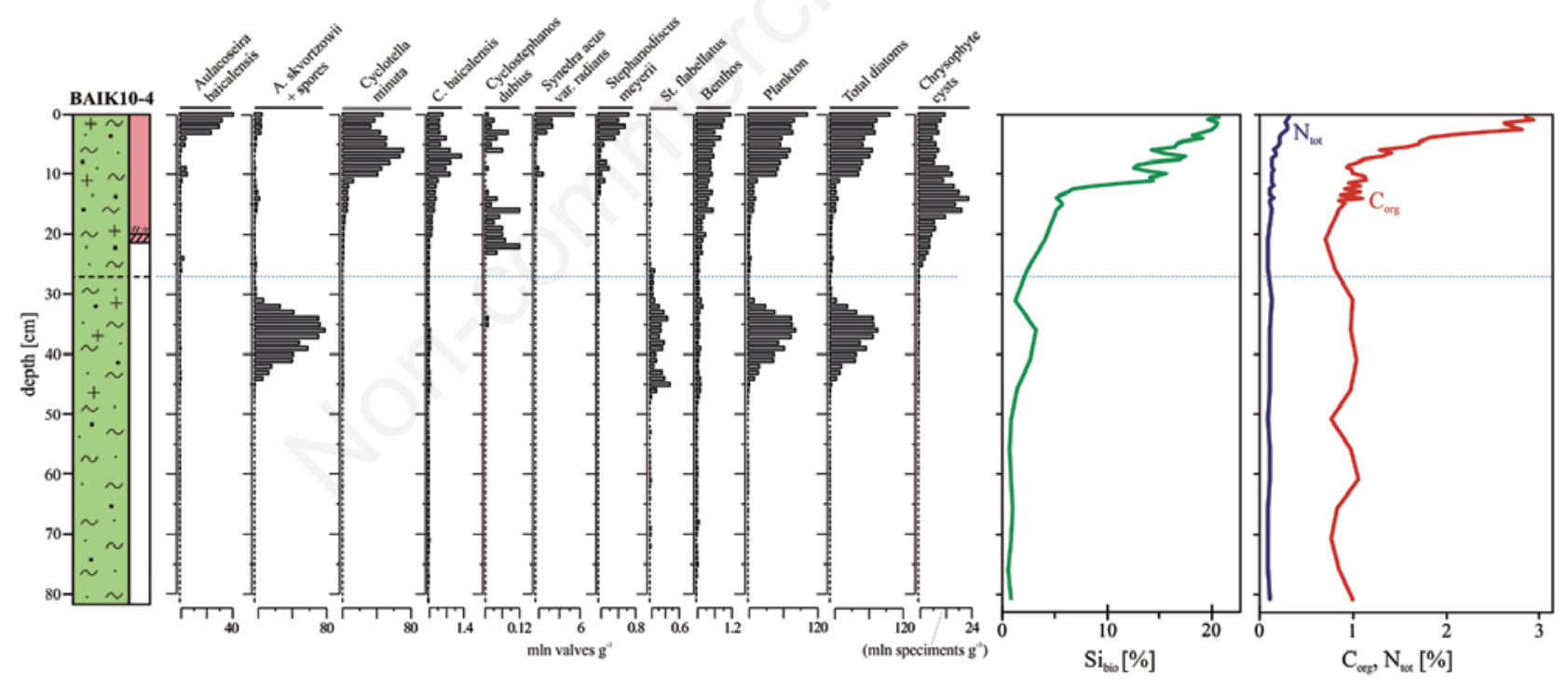

Fig. 2. Lithology, distribution of diatom assemblages and content of $\mathrm{Si}_{\text {bio }}$ and $\mathrm{C}_{\text {org }}, \mathrm{N}_{\text {tot }}$ of shallow-water core BAIK10-4. The dotted line indicates the Holocene/Pleistocene boundary. For the legend of lithology see Fig. 3.

Tab. 1. List of sediment cores taken near Cape Ivanovskii with coordinates, distance from shore, water depth and length.

\begin{tabular}{|c|c|c|c|c|}
\hline Names of cores & Coordinates & Distance from shore $(\mathrm{m})$ & Water depth (m) & Core length $(\mathrm{cm})$ \\
\hline BAIK00-1 & $51^{\circ} 46.065 \mathrm{~N} 104^{\circ} 24^{\prime} 983 \mathrm{E}$ & 3600 & 1366 & 108.5 \\
\hline BAIK08-1 & $51^{\circ} 47.386^{\prime} \mathrm{N} 104^{\circ} 24.893^{\prime} \mathrm{E}$ & 700 & 550 & 76.0 \\
\hline BAIK08-2 & $51^{\circ} 46.077^{\prime} \mathrm{N} 104^{\circ} 25.871^{\prime} \mathrm{E}$ & 3600 & 1366 & 41.9 \\
\hline BAIK10-4 & $51^{\circ} 47.386^{\prime} \mathrm{N} 104^{\circ} 24.893^{\prime} \mathrm{E}$ & 700 & 550 & 82.0 \\
\hline
\end{tabular}


$5.3 \%$ ) and Stephanodiscus meyerii Genkal et Popovskaya (0.04-0.9\%). Very few specimens have been observed of Aulacoseira granulata (Ehrenberg) Simonsen, Aulacoseira subarctica (O. Müller) Haworth. There are just 0.01$2.6 \%$ redeposited diatom species of Pliocene-Pleistocene age: Cyclotella iris Brun et Héribaud, Cyclotella comptaeformica Khursevich, Cyclotella tempereiformica Khursevich, Cyclotella distincta Khursevich, Cyclotella gracilis Nikiteeva et Likhoshway, Stephanodiscus asteroides var. baicalensis Khursevich et Fedenya and Stephanodiscus grandis Khursevich et Loginova.

Another planktonic diatom maximum occurs between $27-48 \mathrm{~cm}\left(0.31-83.4 \times 10^{6}\right.$ valves $\left.^{-1}\right)$. Here the dominating species are represented by Aulacoseira skvortzowii + spores (20.3-98.6\%) and Stephanodiscus flabellatus Khursevich et Loginova (0.3-17.1\%). The number of planktonic diatoms decreases markedly in the interval 49 to $81 \mathrm{~cm}$, showing values of only $0.04-0.56 \times 10^{6}$ valves $\mathrm{g}^{-1}$ (Fig. 2).
Planktonic diatoms dominate diatom assemblages of deepwater sediments (BAIK08-2) with concentrations of 16$263 \times 10^{6}$ valves $\mathrm{g}^{-1}$ (benthic diatoms: $0.15-1.27 \times 10^{6}$ valves $\mathrm{g}^{-1}$ (Fig. 3). They contain higher numbers of chrysophyte cysts $\left(6-56 \times 10^{6}\right.$ specimens $\left.\mathrm{g}^{-1}\right)$ and spiculae $\left(0.5-1.7 \times 10^{5}\right.$ specimens $\mathrm{g}^{-1}$ ). Cyclotella minuta (up to $99 \%$ ), Aulacoseira baicalensis (up to 42\%), A. skvortzowii + spores (up to $19 \%$ ) and Synedra acus (up to $13.2 \%$ ) constitute the main diatom species. Minor quantities are represented by $C y$ clotella baicalensis (up to $2.6 \times 10^{6}$ valves $\mathrm{g}^{-1}$ ), Stephanodiscus meyerii (up to $4.5 \times 10^{6}$ valves $\mathrm{g}^{-1}$ ), Crateriportula inconspicua Flower et Håkansson (up to $0.14 \times 10^{6}$ valves $\mathrm{g}^{-1}$ ), Cyclostephanos dubius (up to $0.3 \times 10^{6}$ valves $\mathrm{g}^{-1}$ ) and Synedra ulna var. danica (Kützing) Grunow (up to $0.34 \times 10^{6}$ valves $\left.\mathrm{g}^{-1}\right)$. Small amounts $(<0.14 \%)$ of reworked diatom species of Pliocene-Pleistocene age have been identified: Stephanopsis costatus Khursevich et Fedenya, Tertiarius baicalensis Khursevich et Fedenya, Cyclotella

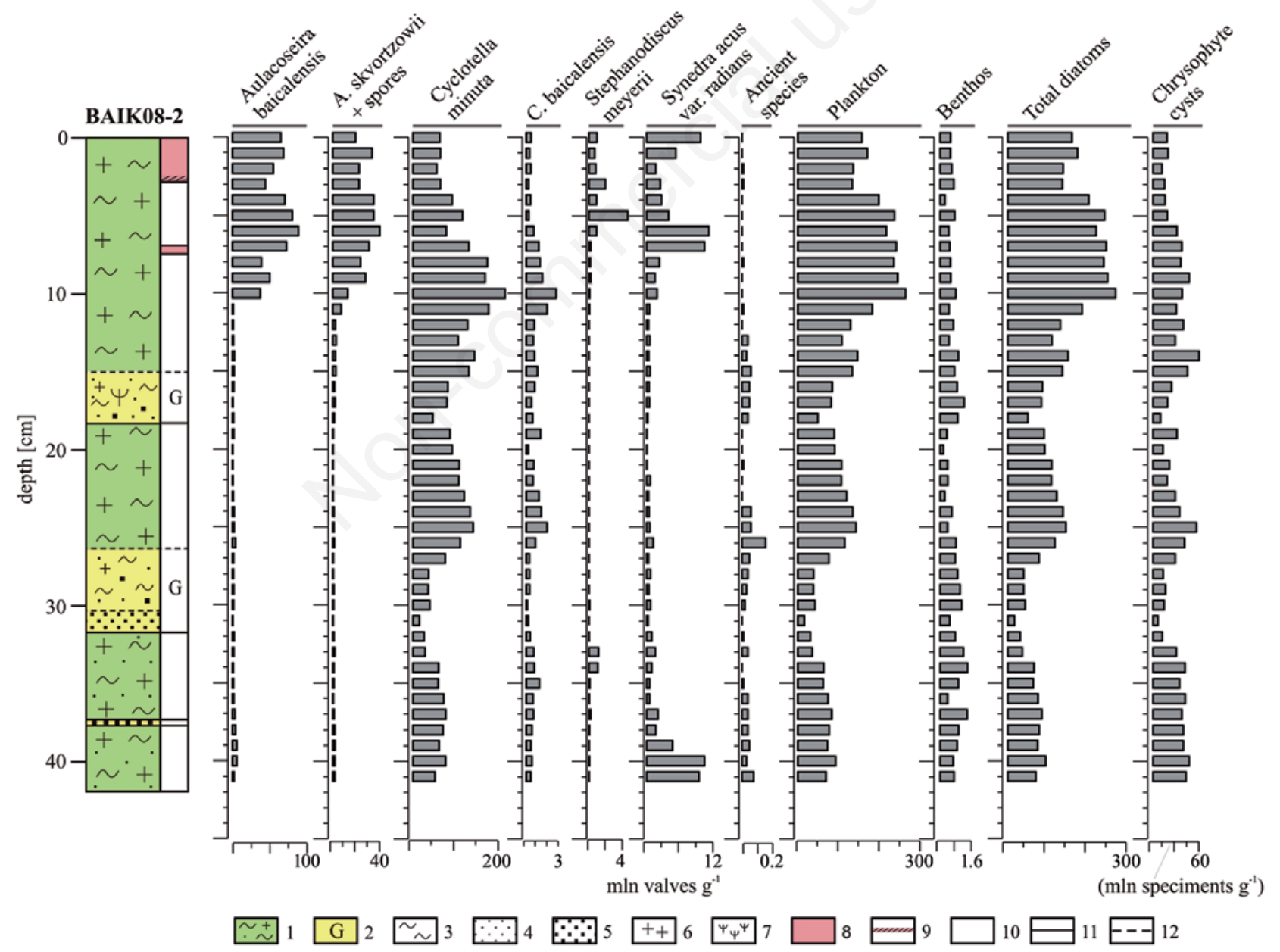

Fig. 3. Lithology and distribution of diatom assemblages of deep-water core BAIK08-2. Legend of lithology: 1, pelagic mud; 2 G, turbidite (graded layer); 3, clay, 4, silt; 5, sand, 6, diatoms; 7, land plant remains; 8, oxidized sediment; 9, Fe/Mn crust; 10, $\mathrm{O}_{2}$-reduced sediment; 11, distinct boundaries between layers, 12, indistinct boundaries between layers. 
tempereiformica, C. comptaeformica et var., Stephanodiscus williamsii Khursevich, Stephanodiscus baicalensis var. concinnis Pomazkina et Likhoshway, Stephanodiscus carconeiformis Khursevich et Loginova, Stephanodiscus formosus Khursevich et Loginova, Stephanodiscus grandis and Stephanodiscus flabellatus (Fig. 3).

Within turbidites of BAIK08-2, at $15 \mathrm{~cm}$ to $18.3 \mathrm{~cm}$ and $26.3 \mathrm{~cm}$ to $31.7 \mathrm{~cm}$, numbers of planktonic diatoms, chrysophytes and spiculae are markedly reduced, whereas the numbers of benthic and ancient diatoms are slightly higher (Fig. 3).

\section{Contents of biogenic silica $\left(\mathrm{Si}_{\text {bio }}\right)$, organic carbon $\left(\mathrm{C}_{\text {org }}\right)$ and total nitrogen $\left(\mathbf{N}_{\text {tot }}\right)$}

Within sediments of shallow-water core BAIK10-4 highest concentrations of $\mathrm{Si}_{\text {bio }}(20.93 \%), \mathrm{C}_{\text {org }}$ $(2.92 \%)$ and $\mathrm{N}_{\text {tot }}(0.30 \%)$ are observed at the top of the core. Concentrations decrease down-core within $25 \mathrm{~cm}$ to minimal values of $0.7 \%\left(\mathrm{Si}_{\text {bio }},\right), 0.7 \%\left(\mathrm{C}_{\text {org }}\right)$ and $0.08 \%$ $\left(\mathrm{N}_{\text {tot }}\right)$ and stay low until the base of the core (Fig. 2). A similar pattern is observed in the pelagic deposits of deepwater core BAIK00-1 (Fig. 4). Highest values of $\mathrm{Si}_{\text {bio }}$ $(25.5 \%), \mathrm{C}_{\text {org }}(3.9 \%)$ and $\mathrm{N}_{\text {tot }}(0.4 \%)$ occur at the top of the core and decrease to $2.0 \%\left(\mathrm{Si}_{\text {bio }},\right), 1.1 \%\left(\mathrm{C}_{\text {org }}\right)$ and $0.1 \%$ $\left(\mathrm{N}_{\text {tot }}\right)$ towards the base of the core. Concentrations within turbidites (graded beds) are distinctly lower compared to pelagic muds. Values of $\mathrm{Si}_{\text {bio }}$ vary between $1.3-14.1 \%$, of $\mathrm{C}_{\text {org }}$ between $0.6-2.3 \%$ and of $\mathrm{N}_{\text {tot }}$ between $0.4-0.1 \%$.

\section{Results of grain size analysis}

Shallow-water sediments (BAIK08-1) contain 48$58 \%$ clay, $16-26 \%$ silt and $23-31 \%$ sand. The fraction $50-$
$250 \mu \mathrm{m}$ contains up to $0.4 \%$ terrestrial plant remains. Deep-water sediments (BAIK08-2) are characterized by $57-68 \%$ clay, $25-30 \%$ silt and only sometimes contain small amounts of sand $(<12 \%)$. The fraction $50-250 \mu \mathrm{m}$ contains up to $42 \%$ diatoms and spiculae, but no terrestrial plant remains. Turbidites, which are intercalated to the pelagic deposits, contain up to $62 \%$ sand. The fraction 50 $250 \mu \mathrm{m}$ of turbidites includes up to $8 \%$ diatoms and spiculae, and up to $2.8 \%$ terrestrial plant remains

Interpretation of grain sizes of pelagic sediments of Lake Baikal may be erroneous if analyses performed on bulk sediment samples, because high amounts of siliceous diatoms, chrysophytes and spiculae generally have a coarsening effect on the grain size distribution. Median grain sizes of $\mathrm{Si}_{\text {bio }}$-free samples (Fig. 4, black line) are up to $15 \mu \mathrm{m}$ smaller than those of bulk sediment samples, which include biogenic siliceous microfossils (Fig. 4, grey line). Siliciclastic material of turbidites shows a different behaviour, as the median of samples without $\mathrm{Si}_{\text {bio }}$ is up to $33 \mu \mathrm{m}$ coarser than the median of bulk sediment samples. These results show a clear distinction between pelagic sediments and turbidites (Fig. 4).

Of the four turbidites in the deep-water core BAIK001 the uppermost turbidite shows an inverse grading. The next two turbidites show at their base maximum grain sizes of $57 \mu \mathrm{m}$ and $52 \mu \mathrm{m}$, respectively (Fig. 4, black line). Grain sizes of $73 \mu \mathrm{m}$ at the base of the lowermost turbidite become finer $(2.6 \mu \mathrm{m})$ towards the clayey top and include a recurrence of coarser fraction in its upper part (Fig. 4, black line).

\section{Mineral composition}

The light mineral fraction of both shallow- and deep-
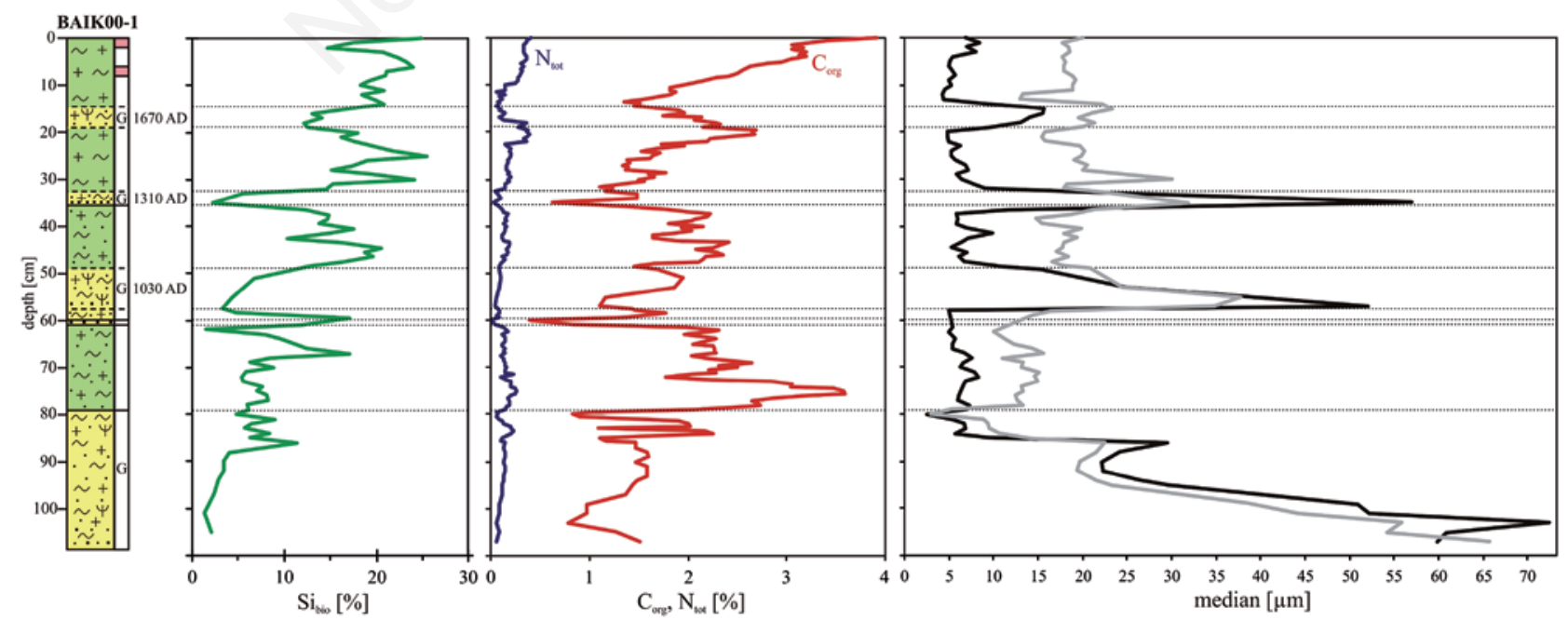

Fig. 4. Lithology content of $\mathrm{Si}_{\text {bio }}, \mathrm{N}_{\text {tot }}, \mathrm{C}_{\text {org }}$, and median grain size distribution of deep-water core BAIK00-1. The black line of the grain size distribution shows results without $\mathrm{Si}_{\text {bio }}$. The grey line shows grain size results including $\mathrm{Si}_{\text {bio }}$. For the legend of lithology see Fig. 3 . 
water sediments, is dominated by quartz, plagioclase, $\mathrm{K}$ feldspar, biotite $(5-32 \%)$, muscovite $(0.4-1 \%)$, chlorite, graphite $(<1 \%)$ and aggregates (up to $2.4 \%$ in shallowwater and up to $39 \%$ in deep-water sediments). Turbidites of the deep-water cores contain up to $56 \%$ biotite, up to $3 \%$ muscovite and 4\% aggregates. The main minerals in the light fraction of the turbidites are quartz and plagioclase.

Remarkably, the shallow-water sediments of core BAIK08-1 contain up to $33.6 \%$ olivine $\left[(\mathrm{MgFe})_{2} \mathrm{SiO}_{4}\right]$ and up to $2.4 \%$ spinel $\left[\mathrm{MgAl}_{2} \mathrm{O}_{4}\right]$ (Tab. 2). These two rare type-minerals characterize rocks of the Sharyzalgaiskaya Series (Early Precambrian) that are beautifully exposed at the famous outcrop of Belaya Vyemka (Melnikov, 2011), which is situated nearby to the shallow-water coring site. Besides these two specific minerals, the heavy mineral fraction of the shallow-water sediments contains amphiboles (mainly hornblende), pyroxenes (hyperstene and diopside), ilmenite, garnet, magnetite, apatite and epidote (Tab. 2). The heavy mineral fraction of the deepwater sediments (BAIK08-2) additionally contains sillimanite, pyrite, sphene, and zircon (Tab. 2). Heavy mineral assemblages of turbidites show clear differences to the pelagic sediments. They contain up to $40 \%$ hornblende $(<19.2 \%$ in pelagic sediments), up to $14.6 \%$ sillimanite $(<2.4 \%$ in pelagic pelagic sediments $)$ and up to $12.6 \%$ epidote $(<2.8 \%$ in pelagic sediments). Concentrations of $<6 \%$ hyperstene (up to $38.2 \%$ in pelagic sediments), and $<8 \%$ diopside (up to $10.8 \%$ in pelagic sediments) are distinctly lower in turbidites.
Of the rare type-minerals of the Sharyzalgaiskaya Series, spinel is absent within all deep-water sediments. Just $0.4-3.4 \%$ of olivine have been observed in pelagic muds and $0.4-1 \%$ in turbidites.

\section{Mineral composition of the tributaries near Cape Ivanovskii}

The light mineral fraction of sediments from the tributaries near Cape Ivanovskii (Fig. 1) contains mainly feldspars (mainly plagioclase), quartz and mica (mainly biotite). The heavy mineral assemblages are dominated by amphiboles (mainly hornblende), pyroxenes (diopside and hyperstene), ilmenite, magnetite, garnet, goethite, epidote, apatite and zircon (Tab. 3). Samples of Stream, near the outcrop of Belaya Vyemka contain small amounts of olivine (1.6\%) and spinel $(0.2 \%)$, Ivanovka Stream just olivine (0.6\%) (Fig. 1, Tab. 3).

\section{DISCUSSION}

Although the two coring sites are less than $3000 \mathrm{~m}$ apart, the sedimentary record of the shallow-water cores (BAIK08-1, BAIK10-4) at $550 \mathrm{~m}$ differs distinctly from the deep-water cores (BAIK00-1, BAIK08-2) at $1366 \mathrm{~m}$.

The uppermost $27 \mathrm{~cm}$, dark-greenish sediments of the shallow-water cores contain the diatom species Aulacoseira baicalensis, Cyclotella minuta, Cyclotella baicalensis, Cyclostephanus dubius, Stephanodiscus meyerii and

Tab. 2. Mineral composition and content (\%) of heavy minerals of fraction 0.05-0.25 mm of shallow-water sediments (BAIK08-1) and of deep-water sediments (BAIK08-2).

\begin{tabular}{|c|c|c|c|c|c|c|c|c|c|}
\hline \multirow[t]{4}{*}{ Minerals* } & \multicolumn{3}{|c|}{$\begin{array}{c}\text { BAIK08-1 } \\
\text { shallow-water }\end{array}$} & \multicolumn{6}{|c|}{$\begin{array}{l}\text { BA IK08-2 } \\
\text { deep-water }\end{array}$} \\
\hline & $5-10$ & $30-35$ & $60-65$ & $0-10$ & $15-18$ & $18-25$ & $28-30$ & $30-31.6$ & $33-40$ \\
\hline & $\mathrm{cm}$ & $\mathrm{cm}$ & $\mathrm{cm}$ & $\mathrm{cm}$ & $\mathrm{cm}$ & $\mathrm{cm}$ & $\mathrm{cm}$ & $\mathrm{cm}$ & $\mathrm{cm}$ \\
\hline & & & & & turbidite & & turbidite & turbidite & \\
\hline Olivine & 33.6 & 21.0 & 28.8 & - & 0.4 & 3.4 & few & 1.0 & 0.4 \\
\hline Spinel & 2.4 & 0.4 & - & - & - & - & - & - & - \\
\hline Hornblende & 17.0 & 22.0 & 26.0 & 16.4 & 22.0 & 10.0 & 27.2 & 40 & 19.2 \\
\hline Hyperstene & 13.6 & 20.0 & 12.8 & 38.2 & 5.0 & 37.4 & 5.0 & 6.0 & 21.4 \\
\hline Diopside & 14.8 & 18.0 & 13.8 & 10.8 & 7.4 & 9.6 & 8.0 & 7.4 & 10.8 \\
\hline Ilmenite & 5.4 & 5.4 & 5.2 & 12 & 10.8 & 17.0 & 10.4 & 4.0 & 7.6 \\
\hline Garnet & 2.8 & 4.8 & 2.8 & 10 & 19.6 & 8.8 & 24.2 & 9.4 & 24 \\
\hline Epidote & 2.8 & 1.6 & 2.2 & 4 & 5.6 & 2.4 & 4.0 & 5.6 & 2.4 \\
\hline Apatite & 1.4 & 2.0 & 3.0 & 2.6 & 2.4 & 3.0 & 4.2 & 4.0 & 4.0 \\
\hline Magnetite & 3.6 & 3.0 & 4.0 & 3.6 & 2.0 & 3.0 & 1.6 & 1.2 & 2.0 \\
\hline Zircon & 0.4 & 0.6 & 0.6 & 1.0 & 1.4 & 1.0 & 0.4 & 0.2 & 1.2 \\
\hline Sphene & 0.2 & 0.4 & few & 1 & 4.4 & 1.0 & 2.0 & 1.4 & 2.0 \\
\hline Pyrite & - & - & - & - & 8.8 & 6.8 & 1.0 & 0.4 & 1.0 \\
\hline Sillimanite & - & - & - & few & 0.8 & 0.2 & 10.2 & 14.6 & 2.4 \\
\hline
\end{tabular}

*The contents of the minerals tremolite, goethite, rutile, leucoxene, tourmaline, chloritoide, staurolite, biotite, distene are $<1 \%$ and are not shown in the table. 
Synedra acus (Fig. 2) that clearly represent Holocene diatom assemblages (Mackay et al. 1998; Edlund and Stoermer 2000). Down-core, the onset of Stephanodiscus flabellatus and the disappearance of the Holocene diatoms mark the transition to Pleistocene sediments (Bradbury et al., 1994; Grachev et al., 2002; Kuzmin et al., 2009) (Fig. 3). Correspondingly, high concentrations of $\mathrm{Si}_{\text {bio }}(20.9 \%), \mathrm{C}_{\text {org }}(2.9 \%)$ and $\mathrm{N}_{\text {tot }}(0.3 \%)$ in Holocene sediments decrease rapidly to minimum concentrations $\left(\mathrm{Si}_{\text {bio }} 0.7 \%, \mathrm{C}_{\text {org }} 0.7 \%, \mathrm{~N}_{\text {tot }} 0.1 \%\right.$ ) during Pleistocene deposition of light grey, terrigenous clayey silts. This transition reflects the dramatic change from depleted lake productivity during the Pleistocene to higher lake productivity during the Holocene (Fig. 2; Qiu et al., 1993; Moore et al., 2011).

Cores at shallow-water sites near Cape Ivanovskii exhibit very low Holocene sedimentation rates of $<0.003 \mathrm{~cm}$ $\mathrm{a}^{-1}$. They are comparable to low sedimentation rates on ridges and banks, which have been observed on Academician Ridge and other elevated parts of the lake (Edlund and Stoermer, 2000; Vologina et al., 2009). There, weak SW-NE currents across the ridge (Hohmann et al., 1997) cause long-term scavenging of fine-grained pelagic particles and prevent a regular pelagic accumulation of sediments. Likewise, near Cape Ivanovskii, persistent contour currents of $0.02-0.15 \mathrm{~m} \mathrm{~s}^{-1}$, measured along the slope (Schmid et al., 2008) are responsible for winnowing of fine particles and cause the reduction of the Holocene sediment record.

Similar to sediments at Academician Ridge (Vologina et al., 2003), a thick oxidized zone (up to $21.5 \mathrm{~cm}$ ) is developed at the top of sediments at the shallow-water site (Fig. 2) that confirms very low rates of sedimentation. Oxidized zones and rates of sedimentation are directly linked to quantity and quality of sedimentary organic matter, as low sedimentation rates allow deeper diffusion of oxygen into sediment pore-water, whereas high sedimentation rates prevent deep oxygen penetration (Mizandrontsev, 1982). Measurements of nutrient fluxes across the sediment/water-interface proved these assumptions with a quantitative interface model of nutrient cycling (Müller et al., 2005) and demonstrated that the thickness of the oxidized zone is time-dependent (Och et al., 2012). Thin oxidized zones atop deep-water cores BAIK00-1 and BAIK08-2 (Figs. 3 and 4) indicate higher sedimentation rates of deposits within deep basin plains of Lake Baikal (Vologina and Sturm, 2009).

Sedimentation at the deep-water site at $1366 \mathrm{~m}$ water depth occurs under normally undisturbed depositional background conditions. Sediments consist of fine-grained, homogenous pelagic mud of autochthonous biogenic material (diatoms, chrysophyte cysts, spiculae of sponges) and minor admixtures of allochthonous, terrigenous particles. These sediments represent continuous, calm, nonturbulent depositional conditions and they are characteristic for the sedimentation of the deep basin plains of Lake Baikal. Diatom assemblages of the sediments (Fig. 3) are characteristic of the Holocene (Mackay et al., 1998). Dating of deep-water core BAIK00-1 by ${ }^{210} \mathrm{~Pb}$ and ${ }^{32} \mathrm{Si}$ revealed sedimentation rates of $0.036 \mathrm{~cm} \mathrm{a}^{-}$

Tab. 3. Mineral composition and content (\%) of heavy minerals of the fraction $0.25-0.05 \mathrm{~mm}$ of sediments from tributaries in the area of Cape Ivanovskii.

\begin{tabular}{|c|c|c|c|c|c|}
\hline \multirow[t]{2}{*}{ Minerals } & \multicolumn{5}{|c|}{ Tributaries* } \\
\hline & Polovinnaya & Bolshaya & Ivanovka & Stream & Shumiha \\
\hline Olivine & - & Few & 0.6 & 1.6 & - \\
\hline Spinel & - & - & - & 0.2 & Few \\
\hline Hornblende & 24.0 & 30.8 & 33.6 & 24.6 & 22.4 \\
\hline Hyperstene & 5.4 & 19.0 & 14.2 & 14.8 & 16.0 \\
\hline Diopside & 24.0 & 20.8 & 25.4 & 33.4 & 33.2 \\
\hline Ilmenite & 14.8 & 12.2 & 10.4 & 8.4 & 11.2 \\
\hline Garnet & 5.0 & 3.0 & 3.6 & 6.6 & 4.0 \\
\hline Epidote & 0.8 & 3.2 & 5.2 & 2.8 & 0.8 \\
\hline Apatite & 1.4 & 3.2 & 2.0 & 1.2 & 1.2 \\
\hline Magnetite & 12.0 & 2.0 & 2.0 & 4.0 & 10.0 \\
\hline Zircon & 1.6 & 1.0 & 0.6 & 0.6 & 0.2 \\
\hline Sphene & 0.4 & 0.8 & 0.6 & Few & Few \\
\hline Goethite & 10.0 & 2.2 & 0.8 & 0.2 & 0.4 \\
\hline Actinolite, Tremolite & - & 0.8 & Few & 1.2 & 0.4 \\
\hline Anatase & - & - & Few & - & - \\
\hline Leucoxene & 0.6 & 1.0 & 1.0 & 0.4 & 0.2 \\
\hline
\end{tabular}

*For the location of tributaries see Fig. 1 . 
${ }^{1}$ (Morgenstern et al., 2013). The pelagic muds of the basin plains are occasionally, interstratified by turbidites (Vologina and Sturm, 2009). Turbidites contain high amounts of terrigenous, sandy material, small amounts of diatoms, chrysophytes and spiculae and show distinctly lower concentrations of $\mathrm{Si}_{\text {bio }}, \mathrm{C}_{\text {org }}$ and $\mathrm{N}_{\text {tot }}$ than the homogenous pelagic muds (Figs. 3 and 4).

Turbidites represent deposits of turbulent, high-energy conditions, triggered by catastrophic events: breakdowns of delta slopes, voluminous mud flows and excessive floods in the catchment (Sturm and Matter, 1978; Girardclos et al., 2007). Alterations of pelagic mud and turbidites indicate that normally calm sedimentation conditions within the deep basins of Lake Baikal are interrupted occasionally by high-energy turbidity currents and by rapid re-deposition of older material from far distance sources (Nelson et al., 1999; Colman et al., 2003; Vologina et al., 2003). Analogical, we suggest distant sources for the turbidites of the deep-water cores BAIK00-1 and BAIK08-2 (Fig. 4) near Ivanovskii Cape. All the more, as the clifflike $\mathrm{N}$-shore of the basin does not contain any large deltas. The turbidites contain diatoms, which are characteristic for Pliocene/Pleistocene. These diatoms do not appear within the normally deposited pelagic muds but are common in deep-water turbidites of other sites (Vologina et al., 2007). Their sources are Pliocene/Pleistocene sediments, which are widespread along the South- and SE-coast of Southern Baikal and are not exposed at the North coast of this basin (Mats, 1985; Imetkhenov, 1987; Atlas of Baikal, 1993; Mats et al., 2001). Therefore, we assume that the turbidites, intercalated to the deep-water pelagic muds at the site of our investigation at the N-coast near Ivanovskii Cape contain material, which formerly was deposited at the distant SE- and S-coast of the basin. During the last millennium three major events have triggered the formation of turbidity currents, which subsequently caused the deposition of three distal turbidites (1030 AD, $1310 \mathrm{AD}$, $1670 \mathrm{AD}$ ) as far as at the deep-water site near Cape Ivanovskii (Morgenstern et al. 2013).

The shallow-water sites of cores BAIK08-1, BAIK104 (Fig. 1) are free of turbidites (Fig. 2). We assume that shallow-water sites could not be reached by turbidity currents, which just followed the thalweg along the flat deep basin plain. Sand content (up to $30.5 \%$ ) of shallow-water sites originate from coastal sources. The near-shore sources are proved by contents of up to $33.6 \%$ olivine and of up to $2.4 \%$ spinel in the deposits of shallow-water core BAIK08-1 (Tab. 2). The two rare minerals characterize the white marbles of the Sharyzalgaiskaya Series (Early Precambrian) at the prominent outcrop Belaya Vyemka near Cape Ivanovskii (Melnikov, 2011). In contrast, the mineral composition of deep-water pelagic muds and of the interstratified turbidites does not contain any spinel and only very small amounts of olivine $(<1 \%)$. Therefore, we suggest that deep-water sediments near the steep north-shore of Southern Lake Baikal are barely influenced by terrestrial particle input from the nearby catchment, despite being deposited less than $3000 \mathrm{~m}$ from the coast.

This is confirmed by the sediments of the tributaries around Belaya Vyemka (Fig. 1), which contain very low contents of olivine $(<1.6 \%)$ and spinel $(<0.2 \%)$ (Tab. 3$)$. It is assumed, therefore, that the transport of these specific minerals from the point source at shore to the depositional sites at the slope takes not place by the direct influx from streams and tributaries but by occasional near-shore, coast-parallel currents. Measured currents along the northshore within the upper part of the water column can reach speeds of up to $0.15 \mathrm{~m} \mathrm{~s}^{-1}$ (Schmid et al., 2008). These currents seem not be able to transport the minerals olivin and spinel as far as to the deep-water sites of the cores BAIK00-1 and BAIK08-2. Traces of destabilization of sediments by seismic activities (Kuzmin et al., 2000, Vologina et al., 2012) or by degassing of gas hydrates (De Batist et al., 2002) have not been observed in either core of shallow- or deep-water sites. The undisturbed deposits near Cape Ivanovskii are, therefore, excellent sedimentary records to analyse recent and past environmental processes in Lake Baikal.

\section{CONCLUSIONS}

For the first time, sediments from two adjacent coring sites (less than $2500 \mathrm{~m}$ apart) in ocean-like Lake Baikal have been studied to define the influence of terrigenous material on near-coast deposits of deep basin sites and to determine the differences between slope and deep basin sedimentation within $3000 \mathrm{~m}$ from the shoreline. The study site near Cape Ivanovskii at the $\mathrm{N}$-shore of southern Lake Baikal was particularly chosen because it is situated close to Belaya Vyemka, a geological outcrop, famous for its white Precambrian marbles containing two rare minerals: olivine $\left[(\mathrm{MgFe})_{2} \mathrm{SiO}_{4}\right]$ and spinel $\left[\mathrm{MgAl}_{2} \mathrm{O}_{4}\right]$. These two minerals have been used as markers to identify the influence of terrigenous input to the near-coast deposits at the site. Up to $33.6 \%$ olivine and $2.4 \%$ spinel have been determined in the shallow-water sediments, whereas the content in the deep-water sediments is only $3.4 \%$ olivine with no spinel. The homogenous, greenish-grey sediments at both shallow-water ( $48-58 \%$ clay, $16-26 \%$ silt $)$ and at deep-water sites (57-68\% clay, $25-30 \%$ silt) are representative of calm depositional conditions (Vologina and Sturm 2009). However, striking differences in Holocene sedimentation rates have been discovered at the shallow-water site $\left(<0.003 \mathrm{~cm} \mathrm{a}^{-1}\right)$ and at the deep-water site $(0.036 \mathrm{~cm}$ $\left.\mathrm{a}^{-1}\right)$. Contour currents of $0.02-0.15 \mathrm{~m} \mathrm{sec}^{-1}$ along the slope (Schmid et al. 2008) are suggested to persistently winnow fine silt and clay particles, thus being responsible for the reduced sedimentation rates at shallow-water sites near Cape Ivanovskii. Low sedimentation rates at shallow- 
water sites (550 $\mathrm{m}$ water depth) cause deep oxidation of the upper part of the sediments down to $22 \mathrm{~cm}$.

As in other parts of the lake, planktonic diatom assemblages and spiculae of sponges dominate the composition of the homogenous sediments (Bradbury et al., 1994). Cyclotella minuta (up to 96.3\%), Aulacoseira baicalensis (up to $62.1 \%$ ) and Aulacoseira skvortzowii (up to 57.2\%) are the main species in shallow-water deposits. Deepwater sediments contain up to $99 \%$ Cyclotella minuta, up to $42 \%$ Aulacoseira baicalensis but higher amounts of chrysophyte cysts and spiculae. Both assemblages clearly represent Holocene diatom communities. The down-core disappearance of Holocene diatoms and the synchronous onset of Stephanodiscus flabellatus in shallow-water cores indicate the transition to deposits of Pleistocene age and very low Holocene sedimentation rates, induced by long-lasting winnowing of particles. Pelagic deep-water sediments at the study site are characterized by much higher sedimentation rates and the occurrence of intercalated turbidites, which reach a thickness of $3 \mathrm{~cm}$ to 29.5 $\mathrm{cm}$, show an upward-grading and contain up to $62 \%$ sand and up to $2.8 \%$ terrestrial plants. Typically they are reduced in planktonic diatoms, chrysophytes and spiculae and contain higher amounts of benthic and ancient (Pliocene/Pleistocene) diatoms. Concentrations of $\mathrm{Si}_{\text {bio }}$ $(<14.1 \%), \mathrm{C}_{\text {org }}(<2.3 \%)$ and $\mathrm{N}_{\text {tot }}(<0.1 \%)$, are distinctly lower in turbidites. We suggest that the sources of the turbidites are situated at far-distant delta depot-centres at the SE- and S-coast of the southern basin of Lake Baikal.

In summary, this study shows striking differences of sedimentation rates at shallow-water and deep-water sites. It proves that pelagic deep-water sediments near steep, cliff-like slopes are barely influenced by terrestrial particle input from the nearby catchment, although they are less than $3000 \mathrm{~m}$ from the coastline.

\section{ACKNOWLEDGMENTS}

The Integration Project of Siberian and Far East Branch of Russian Academy of Sciences (SB-FE-RAS) No. 34 and EAWAG-grant no. 85.145 supported this study. Major scientific, administrative and technical support is thankfully acknowledged to Professor N.M. Budnev (State University Irkutsk) and his team at the NEUTRINO telescope station. We are thankful to Professor E.V. Sklyarov (RAS-SB Institute of Earth Crust) for multiple support, geological information and discussions. I.B. Radziminovich (RAS-SB Institute of Earth Crust) helped greatly with computer procedures and references. We thank I.A. Kalashnikova, S.P. Sumkina, E.G. Poliakova (all RAS-SB Institute of Earth Crust) and T.O. Zelezniakova (RAS-SB Limnological Institute) for sampling and analytical work. Irene Brunner and Alois Zwyssig (both EAWAG) are acknowledged for geochemical and sedimentological analyses. The paper benefitted greatly by scientific contributions of A.W. Mackay
(UCL), who also helped to considerably improve the English. We acknowledge thankfully help, comments and correction by A. Johnson, D.M. Livingstone and A. Wüest (all EAWAG). Comments of two anonymous reviewers and the editors of the Journal of Limnology are thankfully acknowledged.

\section{REFERENCES}

Appleby PG, Flower RG, Mackay AW, Rose NL, 1998. Paleolimnological assessment of recent environmental change in Lake Baikal: sediment chronology. J. Paleolimnol. 20:119-133.

Back S, De Batist M, Strecker MR, Vanhauwaert P, 1999. Quaternary depositional systems in northern Lake Baikal, Siberia. J. Geol. 107:1-12.

Bangs M, Battarbee RW, Flower RJ, Jewson D, Lees JA, Sturm M, Vologina EG, Mackay AW, 2000. Climate change in Lake Baikal: diatom evidence in area of continuous sedimentation. Int. J. Earth Sci. 89:251-259.

Belolaptikov A, Bezrukov LB, Borisovets BA, Budnev NM, Viebush K, Wischnewski R, Gaponenko ON, Garus AA, Gress OA, Gress TI, Danil'chenko IA, Dzhilkibaev Zh AM, Dobrynin VI, Domogatskii GV, Doroshenko AA, Ignat'ev SB, Karle A, Klabukov AM, Klimov AI, Klimushin SI, Koshechkin AP, Kulepov VF, Kuzmichev LA, Lovtsov SV, Lubsandorzhiev BK, Maksimov VN, Maksimova EA, Milenin MB, Mikolajski T, Mirgazov RR, Moseiko NI, Moroz AV, Nikiforov SA, Osipova EM, Pavlov AA, Panfilov AI, Parfenov YuV, Petukhov DP, Pokolev PA, Pocheikin KA, Pokhil PG, Rozanov MI, Rubtsov VYu, Sinegovskii SI, Sokal'skii IA, Tarashchanskii BA, Thon T, Fialkovskii SV, Heukenkamp H, Chenskii AG, Spiering C, Streycher O, 1998. On the nonstationarity of deep Baikal water flows as derived from Neutrino Telescope data. Izv. Atmospheric Ocean Physics 34:78-84.

Bezrukova EV, Bogdanov YA, Williams DF, Granina LZ, Grachev MA, Ignatova NV, Karabanov EB, Kuptsov VM, Kurylev AV, Letunova PP, Likhoshwai EV, Chernyaeva GP, Shimaraeva MK, Yakushin AO, 1991. Deep changes in the North Baikal ecosystem in the Holocene. Doklady AN SSSR 321:1032-1037.

Bondarenko NA, Guselnikova NE, Vorob'eva SS, Logacheva NF, 1993. Species composition of planktonic diatom algae of Lake Baikal and biology of dominant species, p. 72-75. Proc. $5^{\text {th }}$ Workshop on diatom algae: diatom algae as indicators of the changes of climate and environment. Russian Academy of Sciences/Siberian Division, Irkutsk, Russia.

Bradbury JP, Bezrukova YV, Chernyaeva GP, Colman SM, Khursevich GK, King JW, Likoshway YV, 1994. A synthesis of post-glacial diatom records from Lake Baikal. J. Paleolimnol. 10:213-252.

Colman SM, Karabanov EB, Nelson CH, 2003. Quaternary sedimentation and subsidence history of Lake Baikal, Siberia, based on seismic stratigraphy and coring. J. Sed. Res. 73: 941-956.

De Batist M, Klerkx J, Van Rensbergen P, Vanneste M, Poort J, Golmshtok AY, Kremlev AA, Khlystov OM, Krinitsky P, 2002. Active hydrate destabilization in Lake Baikal, Siberia? Terra Nova 14:436-442.

Edlund MB and Stoermer EF, 2000. A 200,000-year, high-reso- 
lution record of diatom productivity and community makeup from Lake Baikal shows high correspondence to the marine oxygen-isotope record of climate change. Limnol. Oceanogr. 45:948-962.

Fietz S, Sturm M, Nicklisch A, 2005. Flux of lipophilic photosynthetic pigments to the surface sediments of Lake Baikal. Global Planet. Change 46:29-44.

Flower RJ, 1998. Paleolimnology and recent environmental change in Lake Baikal: an introduction and overview of the interrelated concurrent studies. J. Paleolimnol. 20:107-117.

Galazi GI, 1993. [Atlas of Lake Baikal].[Book in Russian]. Russian Academia of Science, "Siberia" Program Interdepartmental Scientific Committee of the Siberian Branch of Russian Academy of Science. Federal'naya Sluzhba Geodezii i Kartografii Rossii. Moscow: 160 pp.

Girardclos S, Schmidt OT, Sturm M, Ariztegui D, Pugin A, Anselmetti FS, 2007. The 1996 delta collapse and large turbidite in Lake Brienz. Mar. Geol. 241:137-154.

Goldyrev GS, 1982. [Sedimentation and Quaternary history of the Baikal basin].[Book in Russian]. Nauka, Novosibirsk: 182 pp.

Grachev MA, Likhoshwai YV, Vorob'eva SS, Khlystov OM, Bezrukova EV, Veinberg EV, Goldberg EL, Granina LZ, Kornakova EG, Lazo FI, Levina OV, Letunova PP, Otinov PV, Pirog VV, Fedotov AP, Yaskevich SA, Bobrov VA, Sukhorukov FV, Rezchikov VI, Fedorin MA, Zolotarev KV, Kravchinsky VA, 1997. Signals of the paleoclimates of Upper Pleistocene in the sediments of Lake Baikal. Russ Geol Geophys 38:957-980.

Grachev MA, Gorshkov AG, Azarova IN, Gol'dberg EL, Vorob'eva SS, Zheleznyakova TO, Bezrukova EV, Krapivina SM, Letunova PP, Khlystov OM, Levina OV, Chebykin EP, 2002. [Regular climatic oscillations within millenniums and species formation in Lake Baikal, p. 107-121]. In: S.V. Markin (ed.), [The main regularities of global and regional climatic and environmental changes in Siberia in the Late Cenozoic].[Book in Russian]. IAET SORAN, Novosibirsk.

Granina LZ and Callender E, 2007. Elements of the iron and manganese cycles in Lake Baikal. Geochem Int 45/9:918-925.

Hohmann R, Kipfer R, Peeters F, Piepke G, Imboden DM, Shimaraev MN, 1997. Processes of deep-water renewal in Lake Baikal. Limno.1 Oceanogr. 42:841-855.

Imetkhenov AB, 1987. [Late Cenozoic deposits of the Baikal shore].[Book in Russian]. Nauka, Novosibirsk.

Karabanov EB, 1984. [Turbidity currents and their role in the formation of sedimentary strata, 223-240]. In: G.I. Galazy (ed.), [Lithodynamics and sedimentation in North Baikal].[Book in Russian]. Nauka, Novosibirsk.

Khrenov PM, 1983. [Geological map of the Baikal region. Scale 1:1000000]. VSNIIGGMS [Map in Russian]. Ministerstvo Geologii SSSR, IZK SO AN SSSR.

Kozhovha OM, Izmest'eva LR, 1998. Lake Baikal: evolution and biodiversity. Backhuys Publ., Leiden: 447 pp.

Kuzmin MI, Karabanov EB, Prokopenko AA, Gelety VF, Antipin VS, Williams DF, Gvozdkov AN, 2000. Sedimentation processes and new age constraints on rifting stages in Lake Baikal: results of deep-water drilling. Int. J. Earth Sci. 89: 183-192.

Kuzmin MI, Khursevich GK, Prokopenko AA, Fedenya SA, Karabanov EB, 2009. [Centric diatoms in Lake Baikal during the Late Cenozoic: morphology, systematics, stratigra- phy and stages of development (based on the deep cores of the Baikal Drilling Project)].[Book in Russian]. Academic Publishers "GEO”, Novosibirsk: 374 pp.

Lees JA, Flower RJ, Ryves D, Vologina EG, Sturm M, 1998. Identifying sedimentation patterns in Lake Baikal using whole core and surface scanning magnetic susceptibility. J. Paleolimnol. 20:187-202.

Marks SG, 1991. Road to power: the Trans-Sibirian Railroad and the colonization of Asian Russia, 1850-1917. Cornell University Press: 272 pp.

Mackay AW, 2007. The paleoclimatology of Lake Baikal: a diatom synthesis and prospectus. Earth Sci Rev. 82:181-215.

Mackay AW, Flower RJ, Kuzmina AE, Granina LZ, Rose NL, Appleby PG, Boyle JF, Battarbee RW, 1998. Recent trends in diatom succession in surface sediments from Lake Baikal and their relation to atmospheric pollution and to climate change. Philos. T. Roy. Soc. B 353:1011-1055.

Mackay AW, Ryves DB, Battarbee RW, Flower RJ, Jewson D, Rioual P, Sturm M, 2005. 1000 years of climate variability in central Asia: assessing the evidence using Lake Baikal (Russia) diatom assemblages and the application of a diatom-inferred model of snow cover on the lake. Global Planet. Change 46:281-297.

Mats VD, 1985. [New data on stratigraphy of Miocene and Pliocene deposits in Southern Baikal, p. 36-53]. In: N.A. Florensov (ed.), [Problems of geology and paleogeography of Siberia and the Far East].[Book in Russian]. Irkutsk State Universyti.

Mats VD, Ufimtsev GF, Mandel'baum MM, 2001. [The Cenozoic strata of the Baikal Rift Basin: structure and geologic history]. [Book in Russian]. Sibirian Branch Russian Academy of Science, Filial GEO, Novosibirsk: 252 pp.

Melnikov AI, 2011. [Structural evolution of the metamorphic complexes of ancient shields].[Book in Russian]. GEO Academic Publishers, Novosibirsk: 288 pp.

Mizandrontsev IB, 1982. ["Hydrodynamic concept" of N.M. Strahov and sedimentation in Lake Baikal], p.10-18. In: V.A.Belova and B.F. Lut (eds.), [Late Cenozoic history of lakes in USSR].[Book in Russian]. Nauka, Novosibirsk.

Moore MV, Hampton SE, Izmest'eva LR, Silow EA, 2011. Climate change and the world's "Sacred Sea" - Lake Baikal, Siberia. Bioscience 59:405-417.

Morgenstern U, Ditchburn RG, Vologina EG, Sturm M, 2013. ${ }^{32} \mathrm{Si}$ dating of Lake Baikal sediments of the last millennium. J. Paleolimnol. 50:345-352.

Müller B, Maerki M, Schmid M, Vologina EG, Wehrli B, Wüest A, Sturm M, 2005. Internal carbon and nutrient cycling in Lake Baikal: sedimentation, upwelling, and early diagenesis. Global Planet. Change 46:101-124.

Nelson CH, Karabanov EB, Colman SM, Escutia C, 1999. Tectonic and sediment-supply control of deep rift lake turbidite systems: Lake Baikal, Russia. Geology 27:163-166.

Och LO, Müller B, Voegelin A, Ulrich A, Göttlicher J, Steiniger R, Mangold S, Vologina EG, Sturm M, 2012. New insights into the formation and burial of $\mathrm{Fe} / \mathrm{Mn}$ accumulations in Lake Baikal sediments. Chem. Geol. 330-331:244-259.

Ohlendorf C, Sturm M, 2008. A modified method for biogenic silica determination. J. Paleolimnol. 54:137-142.

Qiu L, Williams DF, Gvorzdkov A, Karabanov E, Shimaraeva M, 1993. Biogenic silica accumulation and paleoproductiv- 
ity in the northern basin of Lake Baikal during the Holocene. Geology 21:25-28.

Potrik'eva GI, 1959. [Bottom sediments of Maleo More].[Article in Russian]. Issues Baikal Limnol Sta 17:205-255.

Rukhin LB, 1969. [The fundamentals of lithology. Doctrine of sedimentary rocks].[Book in Russian]. Nedra, Leningrad: 703 pp.

Salnikova EB, Kotov AB, Levitskii VI, Reznitskii LZ, Melnikov AI, Kozakov AI, Kovach VP, Barash IG, Yakovleva SZ, 2007. Age boundaries of display high-temperature metamorphism in crystal complexes of Irkutsk block of sharyzalgai ledge of Siberian craton base: results of $\mathrm{U}-\mathrm{Pb}$ dating of individual zircon grains. Stratigrafija. Geological correlation. 15:3-19. (in Russian).

Schmid M, Budnev NM, Granin NG, Sturm M, Schurter M, Wüest A, 2008. Lake Baikal deepwater renewal mystery solved. Geophys. Res. Lett. 35:L033223.

Shimaraev MN, Granin NG, Zhdanov AA, 1993. Deep ventilation of Lake Baikal waters due to spring thermal bars. Limno.1 Oceanogr. 38:1068-1072.

Sturm M, Matter A, 1978. Turbidites and varves in Lake Brienz (Switzerland): deposition of clastic detritus by density currents. Spec. Publ. Int. Ass. Sedimentol. 2:147-168.

The INTAS Project 99-1669 Team, 2002. A New Bathymetric Map of Lake Baikal. Open-File Report on CD-Rom, http://users.ugent.be/ mdbatist/intas/disclaimer.htm
Vologina EG, Kashik SA, Sturm M, Vorob'eva SS, Lomonosova TK, Kalashnikova IA, Khramtsova TI, Toshchakov SY, 2007. Results of research into Holocene sediments of the South and Central basins of Lake Baikal (BDP-97 and short cores). Russ. Geol. Geophys. 48:401-413.

Vologina EG, Sturm M, 2009. Types of Holocene deposits and regional pattern of sedimentation in Lake Baikal. Russ. Geol. Geophys. 50:714-719.

Vologina EG, Sturm M, Radziminovich YB, Vorob'eva SS, Shchetnikov AA, 2012. The 1912 earthquake in South Baikal: traces in bottom sediments and gas release into the water column. Russ. Geol. Geophys 53:1342-1350.

Vologina EG, Sturm M, Vorob'eva SS, Granina LZ, 2000. New results of high resolution studies of surface sediments of Lake Baikal. Terra Nostra 9:115-130.

Vologina EG, Sturm M, Vorob'eva SS, Granina LZ, Toshchakov SY, 2003. Character of sedimentation in Lake Baikal in the Holocene. Russ. Geol. Geophys. 44:407-421.

Watanabe T, Nakamura T, Nara F, Kakegawa T, Horiuchi K, Senda R, Oda T, Nishimura M, Matsumoto GI, Kawai T, 2009. High time-resolution AMS 14C data sets for Lake Baikal and Lake Hovsgol sediment cores: changes in radiocarbon age and linear sedimentation rates during the last glacial-Holocene period. Quatern. Int. 205:12-20. 